\title{
自動車用可鐉鋳鉄の現 状
}

\section{1. 可鐉鋳鉄と自動車}

可鍨鋳鉄と自動車とは因縁浅から好ものがあり，可 鋷鋳鉄の進歩発展は自動車工業の高度の要求に追随す るための努力によるところが大きいといわれている。

いま，参考のために 1 台の自動車に使用される可銀

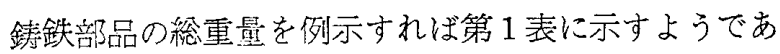
る。これは可鋷鋳鉄製の部品が比較的多量に使用され る大形トラックの例である.

わが国に扔ける最近 5 個年間の自動車用可銀鑆鉄生 産量の推移注第 1 図に揭げるとおりで, 自動車の生産 に呼応して若干の消長はあるが，“年を追って增加の傾 向にあり，31 年から 32 年に加けての飛躍的な堌産は めざましいものがある。これらの数値はそれそれその 年度に晾汀る可錘鋳鉄全生産量の $23 \sim 31 \%$ に相当す る.なお，アメリカでは可鐉錈鉄全生産量の $50 \%$ 以 上が自勤車工業に向けられているといわれている。

第 1 表 自動車シャシ一重量と鋳鉄部品重量の一例

\begin{tabular}{|c|c|c|c|c|}
\hline & & シヤシー & 普通䥔釷 & 可銀鋳鈛 \\
\hline & 量 $\mathrm{kg}$ & 2370 & 285 & 170 \\
\hline 此 & 䅎 $\%$ & 100 & 12 & 7 \\
\hline
\end{tabular}

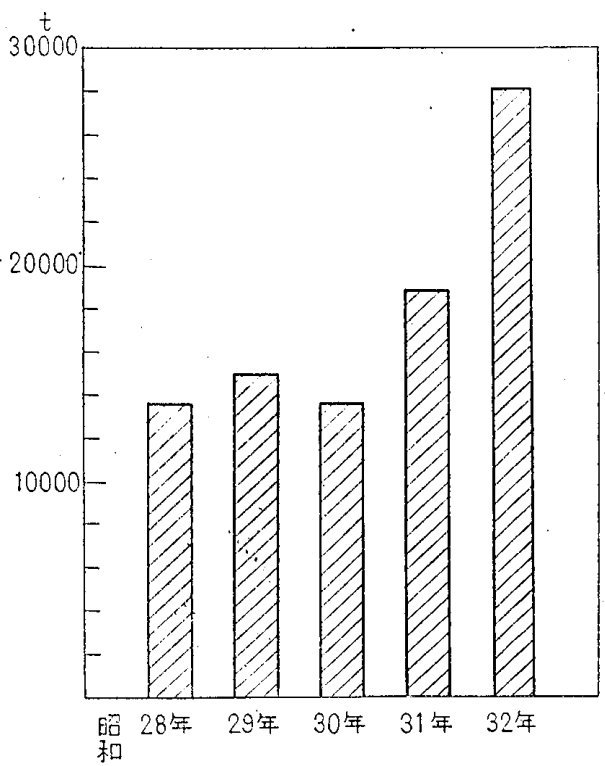

第 1 図 自動車用可銔鋳鉄の生産量

* 原稿受付 昭和 33 年 6 月 17 日.

** トヨ夕自動車工業会社 (蒰知県挙母市下市場前山).
吉見 良 平**

可鐉鋳鉄は自動車に使 第 2 表 主要な可鋁鋳鉄 用される量が多いばかり でなく，第 2 表に示すよ うに主として足回りであ るが重要な部位に使用さ れる、したがって，製品 の検査はきわめて緟重で ある。

わが国の自動車会社の うちトヨタ1社のみが可 部品の例

\begin{tabular}{|c|c|}
\hline トランスそツション & リアカバ \\
\hline ディフアレンシャル & ハウジング \\
\hline$\prime \prime$ & キヤリア \\
\hline$" \prime$ & ケ $-ス$ \\
\hline \multicolumn{2}{|c|}{ ステアリング ボツクス } \\
\hline \multicolumn{2}{|l|}{ スプリング ハンガ } \\
\hline \multicolumn{2}{|l|}{ ホイール ハブ } \\
\hline \multicolumn{2}{|c|}{ クラッチペダル ブラケツト } \\
\hline \multicolumn{2}{|c|}{ ブレーキペダル ブラケツト } \\
\hline エンジン ブラケツ & \\
\hline
\end{tabular}

銀鋳鉄を自家生虐しているが，他はいずれも專門鋳造 工場より購入使用している。

\section{2. 自動車用可鍛鋳鉄の種類}

現在，わが国で自動車に使用されている可雓鋳鉄の ほとんどすべてが黒心可鍛鋳鉄で，第 3 表に示す JIS の第 3 種以上の性質が保証されるものが大部分であ る。

第 3 表 黑心可鏗鋳鉄第 3 種の規格 (JIS G 5701)

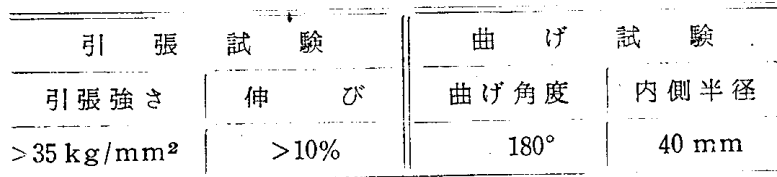

参考, 化学成分 $(\%)$

\begin{tabular}{c|c|c|c|c|c}
\hline $\mathrm{C}$ & $\mathrm{Si}$ & $\mathrm{Mn}$ & $\mathrm{P}$ & $\mathrm{S}$ & $\mathrm{Cr}$ \\
\hline $2 \cdot 30 \sim 2 \cdot 70$ & $0.90 \sim 1.30$ & $<0.4$ & $<0.15$ & $<0.10$ & $<0.03$
\end{tabular}

白心可鍛鉹鉄は，溶接を必要とする部品なぞ特殊な 用途に適することが期待されるが，現在のところ採用 されていないようである。

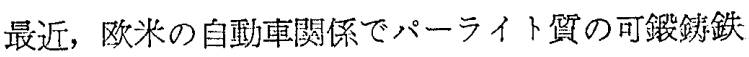
の価值が再評価され，この種の可鐉鋳鉄製部品が忘湤 な発展を示している。わが国でも既に一部の部品につ いて头用に供され，その需裂は漸次增加の兆を呈して いる。

\section{3. 製 造 法}

自動車用可䤨錆鉄部品は比較的軽量肉溥なものが多 く，高い强度と延性が要求され，乙かも形状の複雑な ものが大部分である。したがって，これらの量産に当 
ってはあらゆる点に均一性が䀒要で，全工程にわたる 成染な管理が行われなくては円滑な流れ作業に支障を きたす。

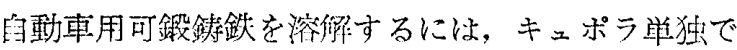
はいかに注望梁く操紧しても高炭素,高いおうが避け られないので十分な效果をあげることは困難である。 したがって，整通にはアーク炉単独あるいはキェポラ とアーク炉あるいは反射㦿の併用により，化学成分， 出湯温度などの调簛を行っている。

もちろん，原材料の管理も重要な因子であるが，自 動車用の場合有䇺成分を含まず均筫な鋼スクラップを 自家調達できる場合が多く，この場合にはそれをさび のない状態で使用できる便利が得られる。

脱酸した溶湯は流動性がよく，その後の㛙なましが 容易になり機㭜的性質も改善されることが知られてか ら，アルミニウムのとりべ添加が広く行われるように なった、また，場合によってはカルシウムシリサイ ド,フェロシリコンなどによる接種も行われることが ある。

造型設備の機械化，自動化は，あらゆる多量生産工 業がそうであるように実に積極かつ慎重に行われる。 たとえば，サンドスリンガ，自動モールディングマシ ンの進歩とともに台車あるいはパレットコンペヤなど の運搬方法の改良もめざましく，混砂，注湯，砂落し まで一貫した流れ作業方式が用いられるなどである。

混砂，造型においても細心の品質管理が要求される ので，型砂は合成砂方式で低水分のものとし，スピー ドマラなどによる高速な混砂方法が綮重な管理のもと に実施され，大量の型砂消費密度に合致するように計 画される。

鋳物の寸法精度を上げて機械加工の削りしろを少く することも自動車用の特徴であるが，その目的にかな いしかも造型作業能率をも上げるために，シェルモー ルド法， $\mathrm{CO}_{2}$ 法など斬新な造型技術が競って採用され ている.シェルモールド法と $\mathrm{CO}_{2}$ 法との比較において は, 現段階としては前者の方に利点が多いので，その 利用激が高い。

しかし現状では，経济性，生産性などの理由でな扔 油中于が主流をなしている。

可鈮鋳鉄特有の内びけ防止に外部给金を用いるべき か，押し湯で行くべきかは，それが造型能力，浴解得 䧱（装入材料に対する製品歩留）への影響が大きいか ら，慎重に考虑されなければならない問題の一つであ る.なお，自動車用可鉔鎕鉄の溶解得率は一般の可銭 鋳鉄に比べて高く，普通 $50 \%$ を越える数值を示す。

また，造型能力向上のため多数込めの複合型も採用
されている。

烧なまし炉は基本的にはバッチ炉と連続炉に分けら れ，ハッチ炖にはエレベータ刑，ベル刑，台車刑があ

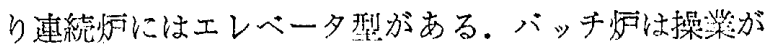
伸縮自在に行われる点が有利であるが, 加熟時, 佮却

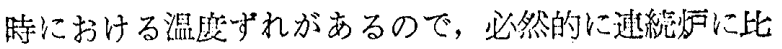
輍して㹸なましサイクルが屒くなる。最終製品のかた

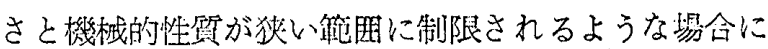
は温度の均一度のすぐれた連続 炉が推奖されている。い装れの 第 4 表 裸烧なまし 型の炉においても最近はふん围 気の調整を行う方向に進んでい る。ふん圈気として使用される ガスの組成の一例を第 4 表に示 用方不組成の例 す.

ふ九圈気調整は酸化脱炭の防止に有効なばかりで

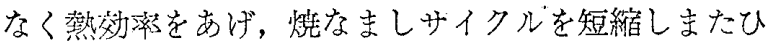
ずみの防止にも有効である。ふん国気調整炉の熱源は 抵抗電熱線あるいはガスだきラジアントチューブによ る.

しかし，わが国では造型関係の著しい進歩に比斡し て焼なまし作業についてはやや立ちおくれの感吕あ りホポットに製品を收容した後粘士類で目ばりを行う 方法もなお多くの工場において採用されている。

また，場合によってはひずみ防止の目的でポット中 に小石を充てんすることもある。

成分に関連して焼なましサイクルの形そのものによ る黒鉛化時間の短縮化も数多い研究の対象になり，予 備加熱あるいは第 2 段黒鉛化の理論とそれに基く燒な ましサイクルの決定などに新しい収獲が得られてい る.

\section{4. パーライト可鍛鋳鉄}

自動菓工業がパーライト可鑹鋳鉄に期待するのに次 に述べる二つの方向䜑るる。

第 1 は鍛造品，鋳鎆の代替として経済性の向上を計

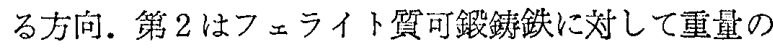
軽減を計る方向である。

最近，自動車の这行中に招ける応力测定が発達し， これが各種の横造部品に銅製品をパーライト可鉔鋳鉄 で置き代える可能性に着想せしめることになった。材 料自体としてはあまり新しくもないパーライト可銀鋳 鉄が急激に脚光を浴びるようになった原因の一つがそ こにあるといわれている。

機械的性賢が信頼できる上に，組織中に黒鉛を包藏 するパーライト可銀鋳鉄は同じかたさの鋼より切削性 
がよく，自己澅滑性を持つ利点がある。

また，可鉔鋳鉄粗形材のコストのう方熱処理費は 10 \%以下であるので，かりにパーライト質の場合フェラ イト質に比较して熱処理費が若干增加するとしても， 重量の軽減は多くの場合コストの節減に結び着く。そ の上，特に自動車においては重量の軽減は性能上から も好ましい因子でもある。

パーライト可鍛鋳鉄の機械的坚質はその化合炭素量 を 0 〜 $9.9 \%$ の闑に変化させることによって相当広い

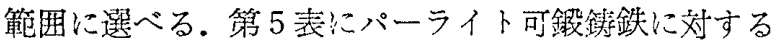
SAE 規格を示す。

第 5 表 SAE パーライト可錀鋳鉄品の嫢格 $\left(\mathrm{kg} / \mathrm{mm}^{2}\right.$ 亿换算)

\begin{tabular}{|c|c|c|c|c|c|}
\hline & 43010 & 48005 & 53004 & 60003 & 70002 \\
\hline $\begin{array}{c}\text { 引張強 } \\
\mathrm{kg} / \mathrm{mm}^{2}\end{array}$ & $>42$ & $>49$ & $>56$ & $>56$ & $>63$ \\
\hline $\begin{array}{c}\text { 降 } 1 \text { 点 } \\
\mathrm{kg} / \mathrm{mm}^{2}\end{array}$ & $>30$ & $>34$ & $>37$ & $>42$ & $>49$ \\
\hline 伸 び \% & $>10$ & $>5$ & $>4$ & $>3$ & $>2$ \\
\hline$H_{B}{ }^{*}$ & $163 \sim 203$ & $179 \sim 228$ & $197 \sim 241$ & $197 \sim 241$ & $241 \sim 285$ \\
\hline
\end{tabular}

*印, 笠囲で示したものは代表例

製造方法としてはおおむね次に述べる三方法に大别 される。

（1）合金添加の方法 第1段黑鉛化にはあまり影 響しないが，第 2 段黒鈴化を阻止して基地中にパーラ イトを残置させるような合金元素を添加する。添加元 素の種類，添加量，組成，肉原，燒なましサイフルな どにより残留する化合孷素量が定まる，添加元素とし ては, マンガン，マンガン一銅，モリブデン，マンガ ンーモリブデン，マンガンーチタン，ビスマスーボロン などがあげられる。

この方法ではフェライト賽のものと同一蹱なましサ イクルを与えることができる便利があるが，その反面 フェライト質のものと同一工埸で䠈造するような場合 には返り材の管理ひ困灘を伴う久点がある。

（2）中絶焼なましの方法 共析セメンタイトがす へて黒欽化する以前に熱処理を中絶する方法である. 一般に第 1 段黒鉛化終了後空泠し，これを $700^{\circ} \mathrm{C}$ 附 近に再加熱し適当な時間保持する。

添加合金は必ずしも要らないが，特別な熱処理疤が 要る．もちろん，前項にあげたような合金元替を添加 すれば更に强度を增すことができる。

（3）再熱処理の方法 フェライト地あるいは空冷 してパーライト地にした可鐙鋳鉄を $850^{\circ} \mathrm{C}$ 附近に再 加熱し，油または適当な液体に筧入してマルテンサイ ト地にしたものを再び $700^{\circ} \mathrm{C}$ 附近で誻もどしを施し 球状パーライト地をうる方法である。肉絠が相違して
もかなり均一な組織が得られるのが特徵である。 この方法は複雑な形状をした部品の燃入に際しては焼 割れやひずみの防止に注意しなくてはならないので， 㧈そらく最も高度の技術が要求せられるであろう。し かし，最大の機峨的性質が期待せられるのもこの方法 である。

（2）および(3)の方法を便筧的にフェライト地の\&の から始めるような場合，脱萩のため表皮層に幅の広い 黑鉛を含まめフェライト層が存在すると，最終組織に までフェライトの表皮層が残り，せっかく内部はパー ライト地になっても痕れ強さが低く耐摩耗性からも好 ましからぬ状態になるおそれがある。

また，パーライト可鐙鋳鉄はフレーム焙入や高周波 烧入により容易にHV 700 の表面(部分)かたさに達 するので，その方面での用途に適する。

現在実用あるいは試用されている部品は，クランク 軸，各種ブラケット類，ディファレンシャルケース， ディフォレンシャルキャリア，ホイールハブ，ミッシ ョンフォーク, ロッカーアーム, 連接棒, ピストンリ ング，シリンダスリーブなに゙である.

更に，クライスラではトランスミッションおよび後 車軸の歯車にも使用する研究が行われているというこ とである。

\section{5. 可鉦鋳鉄と球状黑鉛鋳鉄}

現代における鋳鉄界最大の進展ともいえる球状黒鉛

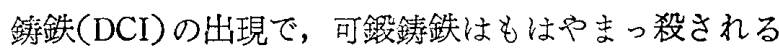
のではないがという筑念さえ持たれた時期があった が，その後 DCI の製造コストを低隇する決定的な解 決策が講ぜられないままに，昨今では両者による販途 の争奪は一芫平衡状態にあるようである。すなわち，

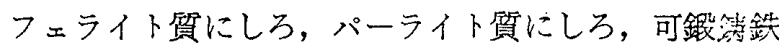

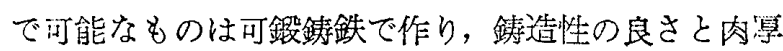
感性の鐩さなどの特性から DCI でなければならな、 ものだけが DCI に向けられるといった状沉である。 特にファェライト質においてしかりである。

DCIの主力はむしろ確実にコスト節減が可能な鋳神用 や錢造品の代替に集中されているように思われる。し 玑，この方问においても，パーライト可鉎鎍鉄之 DCIのいずれを選ぶべきか，現在なおその帰すうは定 まっているとはいえない，現に，自動車用鋳造クラン ク嵮に各社各栐の判断でこの両者の一方が選ばれてい る.その代表例として，ポンチアック(GM) のパーラ イト可錀鉡鉄，タウナス(ドイッフォード)の DCI が あげられる。

闪愿感性，錈造性が許される範囲で，強度を基盤に 


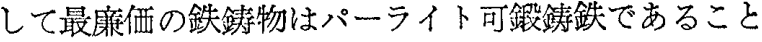
は確かであるが，DCIの製造コストも改善される日が 遠くはないであろう。一方，可鉦錆鉄の側においても， 今日玨にビスマス，ボロンの添加によって比較的肉厚

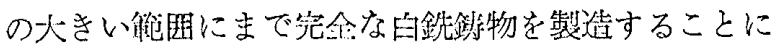

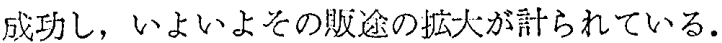

これらの閪にあって，最近国内でスラグ精制による

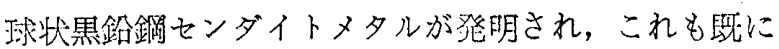
生産の段階にはいらんとしているかに聞いている。こ

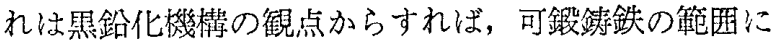
いれることができると考えられ，将来の可銀鋳鉄の進 み方を示睃しているとも推測されるものである。

第6 表抏よび第7表にそれぞれ DCI および球状黒 鉛センダイトメタルの機械的性質を示す。

これらの外にも鉄-カルシウム合金処理法やスラグ の電解による球状黒鉛鋳鉄の製法など新しいプロセス の発表が相ついで行われている.

いずれにしても，現代の鋳鉄界は一大飛躍を試みつ
第6表ＩNCO DCIの規格 $\left(\mathrm{kg} / \mathrm{mm}^{2}\right.$ 炕换算)

\begin{tabular}{|c|c|c|c|c|c|}
\hline & $60-45-10$ & $80-60-03$ & $100-75-04$ & $\mid 120-90-02$ & $60-40-15$ \\
\hline 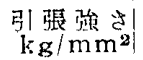 & $>42$ & $>56$ & $>70$ & $>84$ & $>42$ \\
\hline 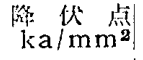 & $>32$ & $>42$ & $>53$ & $>63$ & $>28$ \\
\hline 体 び \% & $>10$ & $>3$ & $>4$ & $>2$ & $>15$ \\
\hline$H_{B}{ }^{*}$ & $140 \sim 190$ & $200 \sim 270$ & $200 \sim 240$ & $24.0 \sim 325$ & $<190$ \\
\hline
\end{tabular}

*印，䈌围で示したものは代表例

第7表 球状黒鉛せンダイトタタルの機械的

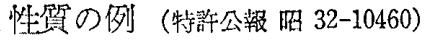

\begin{tabular}{|c|c|c|c|c|c|c|c|}
\hline \multicolumn{5}{|c|}{ 化学成 分 (\%) } & 引張強さ & \multirow{2}{*}{$\%$} & \multirow{2}{*}{ 状 態 } \\
\hline C & $\mathrm{Si}$ & $\mathrm{Mn}$ & $P$ & $s$ & $\left|\mathrm{~kg} / \mathrm{mm}^{2}\right|$ & & \\
\hline \multirow[b]{2}{*}{$1 \cdot 49$} & \multirow{2}{*}{$2 \cdot 78$} & \multirow[b]{2}{*}{0.50} & \multirow[b]{2}{*}{0.03} & & $60 \cdot 2$ & $1 \cdot 5$ & 鋳录し \\
\hline & & & & & $52 \cdot 5$ & $15^{\circ} 5$ & 燒なまし \\
\hline \multirow{2}{*}{$1 \cdot 62$} & \multirow{2}{*}{$2 \cdot 30$} & \multirow{2}{*}{0.49} & \multirow{2}{*}{0.01} & \multirow{2}{*}{0.007} & $68 \cdot 2$ & $2 \cdot 0$ & 鋳放 乙 \\
\hline & & & & & $58 \cdot 9$ & $15 \cdot 0$ & 焼なまし \\
\hline
\end{tabular}

つあることは間違いない事実で，自動車用可鍛鋳鉄も その流れに沿って変って行くことであるう。

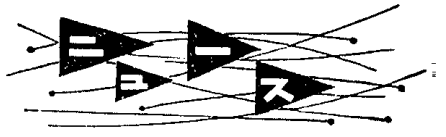

このほぞ，名古屋に本所，大阪，東京などに指導所 をもつ財団法人の自転車技術研究所を 10 月 1 日を期 して設立することになり，その第 1 回の設立発起人会 が開かれた。

同所忹名工試内の自転車開放研究室を発展的解消し て，ここに財団法人改組という形で誕生させるもの で，業界独自の共同研究，指導機関としての役割を果 乙，新しい自転車生産技術の向上，'設備の合理化，コ スト引下げに貢献するものと期待されている。

同研究所の事業計画つぎのとおり。

\section{1. 調 查 研究}

（1）自転車生産技術について次の区分で研究する. 材料（材資，熱処理，銬物，粉末冶金)，望性加工 (䤨造，プレス，ロール成形，型）, 切削(機珹加工), 接合 (溶接, 万う付讨, 有機剂接着), 染装 (防食, 鋈 装, 塗装試耠法), めっき（研摩，めっき）, 構造（設 計，デザイン，性能，强度）。

（2）自転車工場の生产管理，設備の合理化を促進す るために必要な調查研究を行う。

（3）基整的学術售付けを必要とする研究について官 公立その优の研究機関に協力依頼する。

\section{2. 指、導 相 談}

前項の調查研究の成果，その他内外の技術資料にも とづいて活動する。

（1）地区別，項目別，業種別その他適当な類別に上 る技術講習会，瑟談会，公開実験，見学などを行う。

（2）自転車生産技術者の養成扔よび再教育をする。

（3）技術ニュースの発行その他資料の配付を行う。

（4）依頼に上る技得相談, 現場指導, 調查, 試験, 研究，設計，試作などを行う。

\section{3. 工業所有権の所有}

(1).自ら研究考案した工業所有権を取得する.

（2）業界のために必要な他の工業所有権を唫りうけ る。

（3）これら保有する工業所有権を適正に管理運用す る.

なお，同研究所の役員選定の結果，理事長に新䇟正 次氏，専務理事に佐藤信紊氏を決め，理事には日本自 転車工業会副理事長高木幸多郎氏活加業界の 12 名, 監事には中部自転車工業協組理事長传竹良造氏ほか 2 名, 運営委員には科学技術庁審燨官久田太郎氏, 名工 試所長和取松若氏なぼ 9 名である。（服部敏夫） 